\title{
Analysis of Social Influences in the Transition of Czech Students Between Educational Levels and to the Labour Market
}

\begin{abstract}
Petr Hlad'o*
Abstract: The paper deals with the transition of Czech students of lower secondary schools (ISCED 2A) and vocationally oriented upper secondary schools (ISCED 3A and 3C) between educational levels and to the labour market. The theoretical introduction describes the specifics of career decision making of Czech pupils and synthesizes some important empirical findings on social influences on this decision. The core lies in a survey designed by the National Institute of Education, School Counselling Centre and Centre for Further Education of Teachers. The instrument of data collection was questionnaires for students of final years of lower secondary and upper secondary schools. Data collection took place in 2011 at 40 lower secondary $(n=779)$ and 20 vocationally oriented upper secondary schools $(n=442)$. The paper compares the views of these groups of respondents on student's autonomy in the choice of further education and occupation, and social influences on students' career decision-making.

Key words: career decision-making, school choice, career choice, choice of further education and occupation, lower-secondary school, uppersecondary school, significant others, parents, friends, family.
\end{abstract}

\section{Introduction}

Education is one of the key factors which, through the study program completed (Teichler, 2007), field of study (Reimer, Noelke, and Kucel, 2008) and the corresponding range of professions available (Velden and Wolbers, 2007; Heijke and Meng, 2006) co-determines the social status of an individual on the social ladder. The chosen educational path also affects to a large extent the success in the labour market and the possibility to continue in tertiary education. Career decision-making determines not only the individual educational trajectories, but can also pose a potential risk of exclusion at the economic, individual, social, group or spatial level. Whether the chosen course of education and career

\footnotetext{
* Petr Hlad'o, Institut of Lifelong Learning, Mendel University in Brno, Brno, Czech Republic; petr.hlado@mendelu.cz
} 
corresponds to the possibilities and interests of an individual is also important in terms of healthy personality development, individual satisfaction, success and use of his or her social potential (cf. Holland, 1997).

Career decision-making has therefore long been receiving great attention abroad. This is evidenced by a number of studies, mainly in the United States, Great Britain, Germany, Switzerland, Austria, France, etc. (cf. White, 2007; GörtzBrose and Hüser, 2006; Whiston and Keller, 2004; Schulenberg, Vondracek, and Crouter, 1984). Similar trends can be seen recently also in the Czech Republic (e.g. Walterová, Greger, and Novotná, 2009; Walterová et al., 2009; Trhlíková, Vojtěch, and Úlovcová, 2008; Smetáčková, 2005; Katrňák, 2004) and Slovakia (e.g. Vendel et al., 2007a; Vendel et al., 2007b).

\section{Specifics of career decision-making of Czech students of lower and upper secondary schools}

The first group in focus is students of the $9^{\text {th }}$ grades of lower secondary schools (in the Czech Republic known as basic school, základni škola) who are completing compulsory school attendance. These students are usually aged $14-$ 15 years. In their decision-making, students of lower secondary schools (ISCED 2A) have to answer an important question whether to continue in further education at an upper secondary school or to enter the labour market. Only a minor part of lower secondary school students leave for the labour market. After finishing ISCED 2A, most Czech students choose branch-oriented secondary education completed by a school-leaving examination or a vocational/apprenticeship certificate (ISCED 3C). This is also evidenced by the current statistical data (Czech Statistical Office, 2011). The data indicate that the choice of secondary school for the majority of Czech students also means a choice of a profession which is carried through the choice of a specific field of study. This trend is different from other OECD where a greater part of the population goes through general education at the upper-secondary-school level than in the Czech Republic (see Organisation for Economic..., 2009).

The other group is students of graduate years of branch-oriented upper secondary schools completed by a school-leaving examination (ISCED 3A) or a vocational/apprenticeship certificate (ISCED 3C). Studies at a branch-oriented upper secondary school significantly affect an individual and influence his or her further course of education and career perspective. Fields of studies at secondary vocational schools are designed primarily to prepare graduates for profession and in contrast to more general education at secondary grammar schools (gymnázium in Czech), the vocational component is present to a larger extent (Kleňhová and Vojtěch, 2011). Students of these types of upper secondary schools who are leaving the educational system have a sufficient professional 
qualification for entering the labour market. Students of fields of studies both with and without a school-leaving examination have to decide at the end of upper secondary school whether to remain in initial education (tertiary education after upper secondary school is only accessible for graduates of fields of studies with a school-leaving examination) or enter the labour market and look for their first job.

However, psychologists and career theorists agree that adolescents are not sufficiently mature for a responsible career decision-making (e.g. Hirschi and Läge, 2007; Nilsson and Åkerblom, 2001; Super, 1990). Young people lack information about educational possibilities and the world of work and due to their low level of self-knowledge they do not know how high their individual potential is (cf. Gati, Krausz, and Osipow, 1996). They are incapable of fully embracing and understanding all the important objective determinants of such decision-making and do not know themselves very well. The result is that in the transition between educational levels and when entering the labour market they often do not make an optimal choice and soon recognize that their decision was not correct, and in many cases they have to change their previous decision.

Although career decision-making which students of lower secondary and upper secondary schools in the Czech Republic have to make is not an irreversible act, any revision or change of the original decision is associated with expenditure of considerable effort. This situation is described in a textbook for basic school students as an analogy of a train station and a train for the choice of course of education and career is similar to the train station. "Once you get on a certain train, you can change during the journey, and thus decide on your further route, but the basic direction of your journey is already set. The more you want to change it, the more effort it will cost you." (Strádal, 2001, p. 153)

\section{Empirical findings on the influence of social environment on career decision-making}

An analysis of Czech and foreign empirical studies reveals that career decision-making is influenced in particular by social environment in which students live. In this decision-making process, the role of parents is particularly important (ft. Hlad'o, 2010; Görtz-Brose and Hüser, 2006; Whiston and Keller, 2004; Schulenberg, Vondracek, and Crouter, 1984, etc.). It appears the main stimuli of career decision-making are parents (Foskett and Hesketh, 1997). However, the role of parents is far more important. In Anderson's (2004) view, parents are not only the most sought consultants of students but they are also considered the most effective source of advice and information. Furthermore, students list parents as the most important factors influencing their career decision-making (Walterová, Greger, and Novotná, 2009; White, 2007). 
Another issue that appears in studies of career decision-making is the influence of peers, peer groups and friends. Evidence of their influence is represented to a lesser extent than with parents and family (cf. White, 2007). On the basis of an analysis of studies we can conclude that peers play a primary role in career decision-making mainly in providing information (cf. Taylor, 1992).

A frequently discussed issue within career decision-making is the role of teachers and career advisers. Several studies emphasized the marginal role of teachers (Harris, 1992), career advisers (Lawrence, 1992) and career education and counselling in general (Bates, 1990). Students usually place the influence of teachers and counselling staff on their career decision-making behind their families or peers and evaluate their help as less beneficial (Metheny, McWhirter, and O'Neil, 2008).

Career decision-making is a specific and unique process that takes place in the given circumstances in which an individual lives. Although empirical evidence suggests a significant influence of family, research findings are often inconsistent. This situation complicates not only a clarification of the issue but also a synthesis of research findings which could be further built upon.

\section{Empirical survey objectives, methodology and hypotheses}

The empirical survey is focused on finding up-to-date information about career decision-making of students of lower secondary schools and fields of studies of branch-oriented upper secondary schools with and without a school-leaving examination. It was designed by the National Institute of Education, School Counselling Centre and Centre for Further Education of Teachers within the VIP Career II project. The following partial objectives were set in the empirical survey: to evaluate and compare opinions of students as to who in the family should decide on the course of education and career and to evaluate the influence of social environment on the decision-making process.

The instrument of data collection was questionnaires: (1) for students of the $9^{\text {th }}$ grade in the given academic year (in case of lower secondary school students ISCED 2A); (2) for students of final years of branch-oriented upper secondary schools studying in fields of studies providing full secondary vocational education with a school-leaving examination (ISCED 3A) or in three-year fields of studies graduates of which receive secondary vocational education with a vocational/apprenticeship certificate (ISCED 3C).

779 students of lower secondary schools and 442 students of upper secondary schools took part in the research. Of the total number of respondents of upper secondary schools, 244 were students of fields of studies with a school-leaving examination (55\%) and 198 students of fields of studies without a school-leaving 
examination (45\%). Data collection took place in March and April 2011 (academic year 2010/2011) at forty lower secondary schools and twenty upper secondary schools in four of fourteen regions in the Czech Republic.

The data was first analysed using basic statistical techniques. In the case of scale items, relative frequencies were calculated and in the case of social influences, the arithmetic mean was determined, which expresses the coefficient of the influence on career decision-making. Subsequently, hypotheses were tested:

1) In comparison with lower secondary school students, upper secondary school students are more likely to believe that school choice is only their concern and parents should not interfere.

2) In comparison with lower secondary school students, upper secondary school students are more likely to believe that the choice of their future occupation is only their concern and parents should not interfere.

3) The career decision-making of lower secondary school students is, as they believe, influenced by their own decision rather than their parents' activity.

4) The career decision-making of upper secondary school students is, as they believe, influenced by their own decision rather than their parents' activity.

5) There are no differences between lower and upper secondary school students in the evaluation of the influence of friends on their career decision-making.

Dependencies between variables were determined by a chi-square test. Selected data were grouped into four-field tables and odds ratio was calculated for it. The differences between variables were tested using a test of differences between two ratios.

\section{Views of students on their own autonomy in career decision-making}

In connection with career decision-making we aimed at finding out who, in students' views, should decide on the choice of school and profession. In the questionnaire, students were asked to express their opinions on two statements. In the first one, on a four-point scale they had to mark their opinions on whether choice of school should be influenced mainly by parents or whether choice of school is only their concern and parents should not interfere. The second scale question focused on the role of parents in deciding on the choice of further profession (occupation). Students could either mark a view that the choice of future profession should be influenced mainly by parents or that decision-making was only their concern.

Students of lower secondary schools stated in their answers that it is them who 
should decide on the future school. $87 \%$ of surveyed students believe that school choice is mainly their concern and parents should not interfere. Only 13\% of students thought that school choice should be particularly influenced by parents. Even more radical views were expressed by students in case of deciding on the future profession (occupation). $91 \%$ of lower secondary school students were inclined to believe that the choice of future profession is their issue and parents should not interfere. Only 9\% supported the opposite view that the choice of future profession should be influenced mainly by parents.

$91 \%$ of surveyed upper secondary school students stated that school choice was mainly their "business" and parents should not or should rather not interfere. In other words, students should choose their school mainly by themselves. Only $9 \%$ of students were inclined to the view that parents should influence school choice partially or fully. Similarly to students of lower secondary schools, students of upper secondary schools are quite radical in their views on career choice. 94\% of upper secondary school students believed that career choice was only their concern. Mere $6 \%$ of students believed to a greater or lesser extent that the decision on the future profession should be influenced by parents.

The chi-square test showed that there are statistically significant differences in the answers of lower secondary school students regarding autonomy in school choice $\left(\chi^{2}(3)=53.035, p<.000\right.$, Cram. $\left.V=0.210\right)$ and in career choice $\left(\chi^{2}(3)=\right.$ $39.243, p<.000$, Cram. $V=0.181)$. A comparison of students' views on the basis of descriptive statistics shows that students of upper secondary schools have stronger believes than students of lower secondary schools that the choice of school and the choice of future career are solely their concern in which parents should not interfere. This fact is understandable since during adolescence a gradual emancipation from the family occurs in students, which is reflected in the students' views on their own autonomy in the choice of further course of education and career. On the basis of the test performed we reject the hypothesis that students of upper secondary schools believe more strongly than students of lower secondary schools that the choice of school $(O R=1.467, p=.066)$ and the choice of future career $(O R=1.598, p=.063)$ is only their concern in which parents should not interfere.

\section{The influence of the students' social environment on the decision on further course of education and career}

In order to find out what influences are reflected in the students' career decision-making, we presented them with a scale question in the questionnaire: "Who, what and to what extent influenced you in the decision where to go after completing school?" In each source of influence (own decision, parents, siblings, other relatives, friends, friends from social networks, teachers, form 
teacher, educational consultant, school psychologist, pedagogical-psychological consultant, employment office expert), the students could choose from the following scale options: great influence, little influence, and no influence. We calculated relative frequencies and influence coefficients (see Tab. 1, Fig. 1, Fig. 2). It is true that the lower the coefficient is, the higher the perceived degree of influence of the social source is.

Table 1: Social sources of influence on career decision-making as seen by students of lower and upper secondary schools

\begin{tabular}{|c|c|c|c|c|c|c|c|c|}
\hline \multirow{2}{*}{$\begin{array}{c}\text { Social source } \\
\text { of influence } \\
\text { on career } \\
\text { decision-maki } \\
\text { ng }\end{array}$} & \multicolumn{4}{|c|}{$\begin{array}{l}\text { Answers of lower secondary } \\
\text { school students (in \%) }\end{array}$} & \multicolumn{4}{|c|}{$\begin{array}{l}\text { Answers of upper secondary } \\
\text { school students (in \%) }\end{array}$} \\
\hline & $\begin{array}{c}\text { Grea } \\
\mathbf{t} \\
\text { influ } \\
\text { ence } \\
(1)\end{array}$ & $\begin{array}{c}\text { Littl } \\
\text { e } \\
\text { influ } \\
\text { ence } \\
(2)\end{array}$ & $\begin{array}{l}\text { No } \\
\text { influ } \\
\text { ence } \\
(3)\end{array}$ & $\begin{array}{l}\text { Influ } \\
\text { ence } \\
\text { coeffi } \\
\text { cient } \\
(M)^{*}\end{array}$ & $\begin{array}{c}\text { Grea } \\
\text { t } \\
\text { influ } \\
\text { ence } \\
(1)\end{array}$ & $\begin{array}{c}\text { Littl } \\
\text { e } \\
\text { influ } \\
\text { ence } \\
(2)\end{array}$ & $\begin{array}{l}\text { No } \\
\text { influ } \\
\text { ence } \\
(3)\end{array}$ & $\begin{array}{l}\text { Influ } \\
\text { ence } \\
\text { coeffi } \\
\text { cient } \\
(M)^{*}\end{array}$ \\
\hline (Student's) & 91.2 & 8.2 & 0.5 & 1.09 & 63.0 & 27.8 & 9.3 & 1.46 \\
\hline $\begin{array}{l}\text { Own decision } \\
\text { Parents }\end{array}$ & 40.3 & 55.5 & 4.1 & 1.64 & 27.6 & 55.1 & 17.3 & 1.90 \\
\hline Siblings & 7.4 & 27.5 & 65.1 & 2.58 & 8.2 & 28.5 & 63.3 & 2.55 \\
\hline Friends & 9.6 & 48.5 & 41.9 & 2.32 & 12.1 & 46.0 & 41.8 & 2.30 \\
\hline $\begin{array}{l}\text { Friends from } \\
\text { social }\end{array}$ & 2.0 & 11.2 & 86.9 & 2.85 & 2.1 & 10.8 & 87.1 & 2.85 \\
\hline $\begin{array}{l}\text { networks } \\
\text { Teachers } \\
\text { (other than } \\
\text { form teacher) }\end{array}$ & 4.2 & 31.3 & 64.5 & 2.60 & 4.0 & 19.6 & 76.5 & 2.72 \\
\hline Form teacher & 2.3 & 33.9 & 63.8 & 2.62 & 4.0 & 22.0 & 74.0 & 2.70 \\
\hline $\begin{array}{l}\text { Educational } \\
\text { consultant }\end{array}$ & 5.2 & 26.4 & 68.4 & 2.63 & 3.3 & 12.1 & 84.6 & 2.80 \\
\hline $\begin{array}{l}\text { School } \\
\text { psychologist }\end{array}$ & 1.6 & 7.1 & 91.3 & 2.90 & 2.3 & 5.8 & 91.8 & 2.89 \\
\hline $\begin{array}{l}\text { Pedagogical-ps } \\
\text { ychological }\end{array}$ & 5.9 & 18.1 & 76.0 & 2.70 & 2.6 & 6.3 & 91.1 & 2.89 \\
\hline $\begin{array}{l}\text { consultant } \\
\text { Employment }\end{array}$ & 2.6 & 19.8 & 77.6 & 2.75 & 3.0 & 13.8 & 83.2 & 2.80 \\
\hline Other relatives & 7.1 & 43.5 & 49.4 & 2.42 & 5.9 & 24.6 & 69.5 & 2.64 \\
\hline
\end{tabular}




\section{Acta Technologica Dubnicae \\ volume 3, 2013, issue 1}

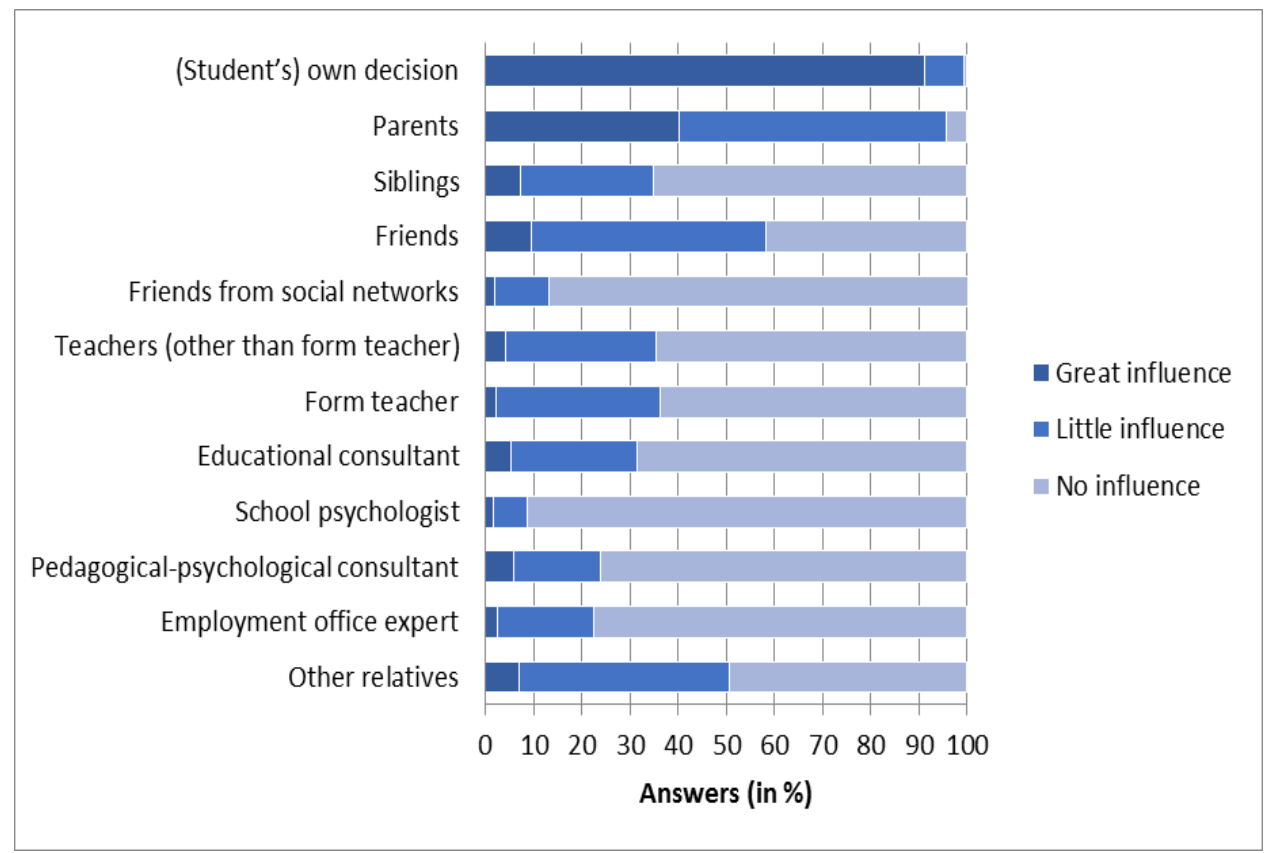

Fig. 1. Social sources of influence on career decision-making as seen by students of lower secondary schools

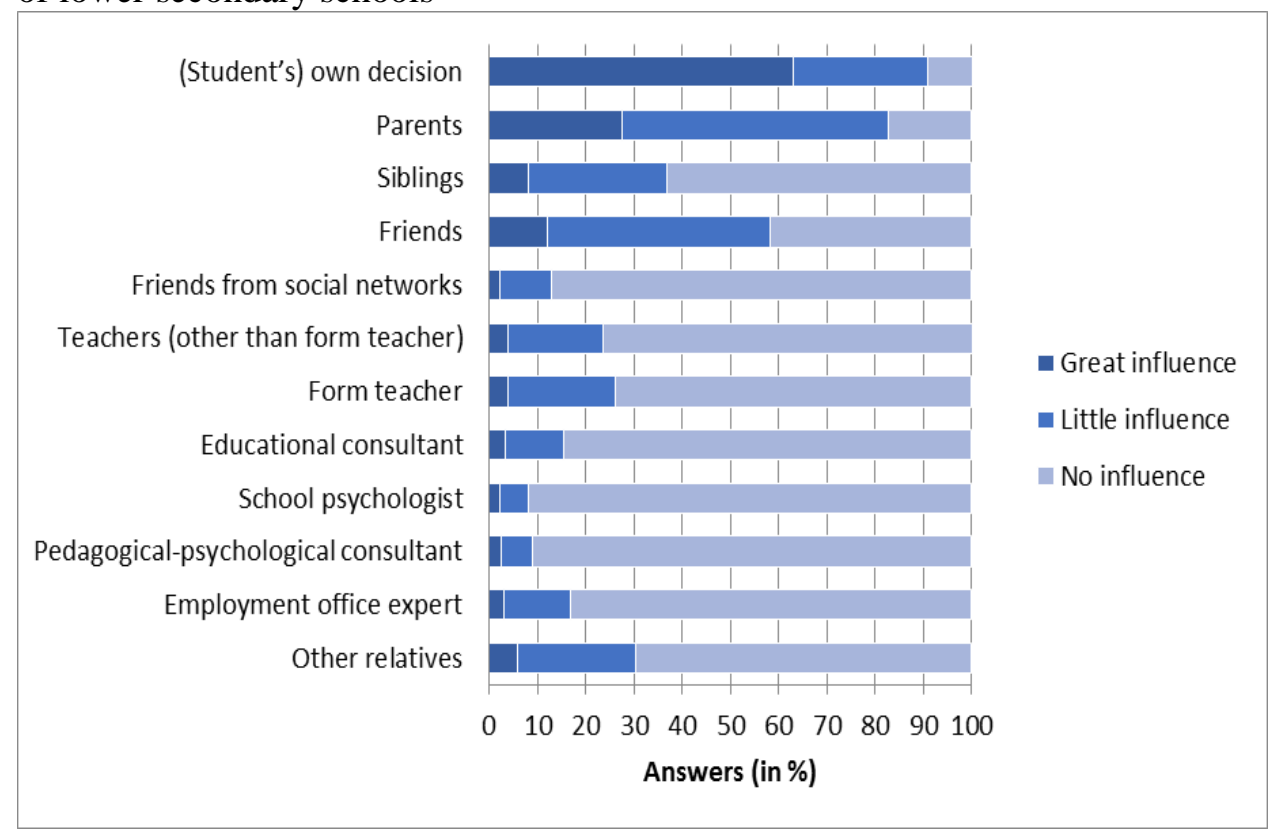

Fig. 2. Social sources of influence on career decision-making as seen by students of upper secondary schools 
Students of both lower secondary schools $(M=1.09)$ and upper secondary schools $(M=1.46)$ attributed the greatest influence on decision-making to their own decision. In both groups of respondents, their "own decision" placed first, based on the influence coefficient.

$91 \%$ of lower secondary school students stated that they had a great influence on the decision "where to go after school", $8 \%$ had little influence and only $1 \%$ had no influence. $63 \%$ of surveyed upper secondary school students believed that it was them who had a great influence on the decision, $28 \%$ were inclined to little influence and $9 \%$ of students said they had no influence on the decision what to do after completing upper secondary school. Since the chi-square test proved statistically significant differences $\left(\chi^{2}(2)=155.090, p<.000\right.$, Cram. $\left.V=0.358\right)$ in answers of both groups of respondents, we calculated the odds ratio for the aggregated values in the four-field table. It appeared that students of lower secondary schools attribute to themselves almost six times greater influence on the decision "where to go after school" than students of upper secondary schools do $(O R=6.124, p<.000)$.

The influence of parents on the students' career decision-making ranked second. It follows from the values of the influence coefficient that students of both lower secondary schools $(M=1.64)$ and upper secondary schools $(M=1.90)$ attribute to parents, on average, fairly little influence. Approximately $40 \%$ of lower secondary school students attribute a great influence to parents. Almost $56 \%$ of students attribute little influence to parents and $4 \%$ attribute no influence. Only $28 \%$ of upper secondary school students attribute a great influence to parents. 55 $\%$ of students admit little influence of parents and $17 \%$ attributed them no influence.

Students of lower $(O R=15.207, p<.000)$ and upper secondary schools $(O R=$ $2.047, p<.001)$ are, as they believe, influenced by their own decision more strongly than by the influence of parents, which corresponds with the findings of Czech as well as foreign studies (cf. Walterová, Greger, and Novotná, 2009; Beinke, 2006; Smyth, 1993; Forster, 1992; Walford, 1991; Thomas and Dennison, 1991). It follows from a more detailed analysis that a greater influence is attributed to parents by lower secondary school students $(O R=$ $1.769, p<.05)$.

Although students tend to disparage the influence of parents on career decision-making, our empirical study showed that in fact they do use their advice in their decision-making. Approximately $20 \%$ of lower secondary school students use their parents" advice "where to go after school" fully and $69 \%$ use their advice in part. Only $8 \%$ of lower secondary school students do not use their parents' advice at all. Remaining 3\% of students either did not receive any advice from their parents or were not able to answer this question. Approximately $12 \%$ of upper secondary school students use their parents' advice in their career decision-making fully and $72 \%$ use their advice in part. Only $8 \%$ of upper secondary school students do not use their parents' advice at all. The 
remaining students either did not receive any advice from their parents or were not able to answer this question.

Other social sources had a smaller influence on students' career decision-making. Parents were followed by friends (the influence coefficient being $M=2.32$ in lower secondary school students and $M=2.30$ in upper secondary school students). No statistically significant differences between lower and upper secondary school students have been proven in the evaluation of the friends' influence on career decision-making $\left(\chi^{2}(2)=155.090, p=.364\right.$, Cram. $V=0.041)$. The fact that, based on the influence coefficient, friends ranked third is understandable. In this development period, students separate gradually from their parents. Increasingly important roles in their lives are played by peers. They are the source of social learning and serve as a support in the process of creating one's own identity. Students try to find someone among peers who they could absolutely trust and with whom they could share their inner feelings. Friendships become an important source of emotional support, understanding, they help develop social skills and provide corrective experience. In case of lower secondary school students, friends were followed by other relatives $(M=2.42)$, siblings $(M=2.58)$, teachers $(M=2.60)$, form teachers $(M=2.62)$, educational consultants $(M=2.63)$, pedagogical-psychological consultants $(M=2.70)$, employment office experts $(M=2.75)$, friends from social networks $(M=2.85)$, and school psychologists $(M=2.90)$.

In case of upper secondary school students, friends were followed by siblings $(M=2.55)$, other relatives $(M=2.64)$, form teachers $(M=2.70)$, teachers $(M=2.72)$, educational consultants $(M=2.80)$, friends from social networks $(M=2.85)$, school psychologists, and pedagogical-psychological consultants (both $M=2.89$ ).

Testing of the students' answers using the chi-square test did not prove any statistically significant differences between the evaluation of influence of relatives, siblings, teachers, form teachers, educational consultants, pedagogical-psychological consultants, employment office experts, friends from social network and school psychologists on career decision-making of lower and upper secondary school students.

\section{Discussion and conclusion}

Although students of lower and upper secondary schools tend to believe that career decision-making in the transition between educational levels and to the labour market should be mainly an autonomous concern of a student, our findings show a considerable influence of the family. We have found out that students at both levels of education are in their career decision-making influenced more strongly by parents than they are by their siblings, other 
relatives, teachers and career consultants. Previously conducted research studies show that the form of influence is set by the family environment and its characteristics but also by the functionality of the family, emotional support, interactions, communications, models in family and overall support from parents (cf. Whiston and Keller, 2004; Schulenberg, Vondracek, and Crouter, 1984).

Despite the mentioned importance of friends, relationship with parents is still in the first place. Especially in the case of emotional problems, relationship conflicts and making important life steps they first contact their parents and only in the second place they seek friends, classmates and other peers (Langmeier and Krejčířová, 2006).

We have found out that the influence of siblings and broad family (grandparents, aunts, uncles, cousins, etc.) on students' career decision-making is rather negligible. Despite this finding their role in students' career decision-making is significant. Siblings are a source of challenge and competition, a means for comparing capabilities and forming professional identity (Altman, 1997). Older siblings are an important source of information about schools and a factor influencing the formation of future plans related to education and profession (Tucker, Barber, and Eccles, 2001). The effect of other relatives rests mainly in indirect influence. Relatives who carry out an interesting profession become models for some students (Kučera, 2005). It is common to share work stories within broad family, which inspire and influence students in their career decision-making. Students may be influenced by how the relatives talk about work or education; or members of broad family form students' attitudes towards education, work and individual occupations (Lankard, 1995).

In terms of teaching and counselling practice we have to point out the very low influence of teachers and counsellors. Teachers and counselling staff also play a specific role in career decision-making. Teachers assess a student in each subject. A qualified teacher is able to diagnose not only the level of knowledge and skills, but also manifestations of talent, interests and possible learning difficulties of the student. Teachers along with parents also act in shaping educational and professional aspirations. Teachers help individuals with the formation of their real professional goal and perspective, and equip them with competences necessary for self-knowledge, planning and decision-making. Since students spend a lot of time at school, teachers have a considerable potential to become a key source of information, advice and help. Moreover, school subjects provide enough space for quality influence from the part of teachers, because they can systematically develop students' interest in the field, provide qualified information on fields of education, content and perspectives of individual professions.

The finding that students and parents attribute a lower degree of influence to counselling staff does not probably stem from the poor quality of counselling services but rather from their infrequent use by students. We see causes of this trend in students' insufficient knowledge about information and counselling 
possibilities of the career counselling subjects, little experience with their use, and their unsatisfactory accessibility.

Although it is not possible to unambiguously determine how the roles of each actor in career decision-making change in time, parents, friends, siblings and broad family are directly as well as indirectly involved in the whole decision-making process. Despite evidence of a significant influence of the family we still know very little about the role of parents in career decision-making. An important question for further research is how parents affect the decision-making process in the transition between educational levels or to the labour market and influence students' final decisions.

\section{References}

ALTMAN, J. H.: Career development in the context of family experiences. In: FARMER, H. (ed.): Diversity and women's career development: From adolescence to adulthood Thousand Oaks: Sage, 1997.

ANDERSON, S. et al.: 17 in 2003 - Scotland's young people: Findings from the Scottish school leavers survey. [online]. http://dera.ioe.ac.uk/5617/1/0033791.pdf

BATES, I.: The politics of career education and guidance. In: British Journal of Guidance and Counselling, vol. 18, 1990, n. 1, p. 66-83.

BEINKE, L. Der Einfluss von Peer Groups auf das Berufswahlverhalten von Jugendlichen. In: BLEY, N. - RULLMAN, M. (eds.): Übergang Schule und Beruf, Recklinghausen: Wissenswertes für Lehrkäfte und Eltern, 2006.

Czech Statistical Office: Statistická ročenka České republiky: 2011. Praha: Český statistický úřad, 2011.

FORSTER, P.: Whose choice is it anyway? In: Managing Schools Today, vol.1, 1992, n. 6, p. 36-37.

FOSKETT, N. H. - HESKETH, A. J.: Constructing choice in contiguous and parallel markets: Institutional and school leavers' responses to the new post-16 marketplace. In: Oxford Review of Education, vol. 23, 1997, n. 3, p. 299-319.

GATI, I. - KRAUSZ, M. - OSIPOW, S. H.: A taxonomy of difficulties in career decision making. In: Journal of Counseling Psychology, vol. 43, 1996, n. 4, p. $510-526$.

GÖRTZ-BROSE, K. - HÜSER, H.: Zum Einfluss von Eltern auf das Berufswahlverhalten von Jugendlichen. In: BLEY, N. - RULLMANN, M. (eds.): Übergang Schule und Beruf: Aus der Praxis für die Praxis, Recklinghausen: Wissenswertes für Lehrkäfte und Eltern, 2006. 
HARRIS, S. A.: Career on the margins? The position of career teachers in schools. In: British Journal of Sociology of Education, vol.13, 1992, n. 2, p. 163-176.

HIRSCHI, A. - LÄGE, D.: The relation of secondary student's career choice readiness to a six-phase model of career decision-making. In: Journal of Career Development, vol. 34, 2007, n. 2, p. 164-191.

HLAĎO, P.: Vliv sociálního okolí na kariérové rozhodování žáků při přechodu do vyššího sekundárního vzdělávání. In: Pedagogická orientace, vol. 20, 2010, n. 3, p. 66-81.

HOLLAND, J. L.: Making vocational choices. A theory of vocational personalities and work environments. Odessa, FL: Psychological Assessment Resources, 1997.

KATRŇÁK, T.: Odsouzeni $k$ manuální práci: vzdélanostní reprodukce $v$ dělnické rodině. Praha: Sociologické nakladatelství, 2004.

KLEŇHOVÁ, M. - VOJTĚCH, J.: Přechod absolventů střednich škol do terciárniho vzdělávání. Praha: Národní ústav odborného vzdělávání, 2006.

KUČERA, M.: Profi-volba v hnědé třídě. In Profi-volba z deváté tř́dy. Prague: Charles University, 2005.

LANGMEIER, J. - KREJČÍŘOVÁ, D.: Vývojová psychologie. Praha: Grada Publishing, 2006.

LANKARD, B. A.: Family role in career development. In: ERIC Digest, 164, 1995, p. 1-7.

LAWRENCE, D.: The career officer: A marginalised member of the education family? In: School Organisation, vol. 12, 1992, n. 1, p. 99-111.

METHENY, J. - MCWHIRTER, E. H. - O'NEIL, M. E.: Measuring perceived teacher support and its influence on adolescent career development. In: Journal of Career Assessment, vol. 16, 2008, n. 2, p. 218-237.

NILSSON, P. - ÅKERBLOM, P.: Kariérové poradenství pro život: poradenská metoda budoucnosti. Brno: P. F. Art, 2001.

Organisation for Economic Co-operation and Development: Highlights from Education at a Glance 2008. Paris: OECD, 2009.

REIMER, D. - NOELKE, C. - KUCEL, A.: Labor market effects of field of study in comparative perspective. In: An analysis of 22 European countries. International Journal of Comparative Sociology, vol. 49, 2008, n. $4-5$, p. 233-256.

SCHULENBERG, J. E. - VONDRACEK, F. W. - CROUTER, A. C.: The influence of the family on vocational development. In: Journal of Marriage and the Family, vol. 46, 1984, n. 1, p. 129-143.

SMETÁČKOVÁ, I.: Genderové aspekty přechodu žáků a žákyñ mezi vzdělávacimi stupni. Praha: Sociologický ústav AV ČR, 2005.

SMYTH, J.: A socially critical view of the self-managing school. London: Falmer Press, 1993. 
STRÁDAL, J.: Člověk a svět práce pro 6.-9. ročník základních škol. Připrava na volbu povolání. Praha: Fortuna, 2001.

SUPER, D. E.: A life-span, life-space approach to career development. In: BROWN, D. - BROOKS, D. (eds.): Career choice and development: Applying contemporary theories to practice. San Francisco, CA: JosseyBass, 1990.

TAYLOR, M. J.: Post-16 options: Young people's awareness, attitudes, intentions and influences on their choice. In: Research Papers in Education, vol. 7, 1992, n. 3, p. 301-335.

TEICHLER, U.: Does higher education matter? Lessons from a comparative graduate survey. In: European Journal of Education, vol. 42, 2007, n. 1, p. 11-34.

THOMAS, A. - DENNISON, B.: Parental or pupil choice: Who really decides in urban schools? In: Education Management and Administration Leadership, vol. 19, 1991, n. 4, p. 243-251.

TRHLÍKOVÁ, J. - VOJTĚCH, J. - ÚLOVCOVÁ, H.: Rozhodování žákì při volbě vzdělávací cesty a úspěšnost vstupu na trh práce: sonda založená na šetřeni absolventů středních škol, kteři se zúčastnili jako patnáctiletí výkumu PISA-2003 a vybraného vzorku jejich zaméstnavatelů. Praha: Národní ústav odborného vzdělávání, 2008.

TUCKER, C. J. - BARBER, B. L. - ECCLES, J. S.: Advice about life plans from mothers, fathers, and siblings in always-married and divorced families during late adolescence. In: Journal of Youth and Adolescence, vol. 30, 2001, n. 6, p. 729-747.

VELDEN VAN DER, R. K.W. - WOLBERS, M. H. J.: How much does education matter and why? The effect of education on socio-economic outcomes among school-leavers in the Netherlands. In: European Sociological Review, vol. 23, 2007, n. 1, p. 65-80.

VENDEL, Š. et al.: Výskum školskej a profesijnej orientácie žiakov: výsledky Bratislavského kraja. Bratislava: Štátny pedagogický ústav, 2007a.

VENDEL, Š. et al.: Výskum školskej a profesijnej orientácie žiakov: výsledky Slovenska s dôrazom na mimobratislavské regióny. Bratislava: Štátny pedagogický ústav, 2007b.

WALFORD, G.: Choice of school at the first city technology college. In: Educational Studies, vol. 17, 1991, n. 1, p. 65-75.

WALTEROVÁ, E. et al.: Přechod žákư a žákyñ ze základní na střední školu: pohledy z výzkumů. Brno: Paido, 2009.

WALTEROVÁ, E. - GREGER, D. - NOVOTNÁ, J.: Volba střední školy ve vzdělávací dráze žákư. Brno: Paido, 2009.

WHISTON, S. C. - KELLER, B. K.: The influence of the family of origin on career development: A review and analysis. In: The Counseling Psychologist, vol. 32, 2004, n. 4, p. 493-568.

WHITE, P.: Education and career choice: A new model of decision making. New York: Palgrave Macmillan, 2007. 